(30) 医器学 Vol. 58, No. 4 (1988)

なわち $\mathrm{S} / \mathrm{N}$ 比にして約 $45 \mathrm{~dB}$ となった.これらの 結果から, 目標とする分解能 $1^{\circ}$ の得られる領域は水 平，垂直軸それぞれ約 $\pm 20 \sim 25^{\circ}$ となった. 実用的に は， $\pm 25 \sim 30^{\circ}$ の計測域があれば十分であるから，概 ね満足できる結果といえ, 本システムは十分実用に供 せるものと考えられる.

4. 今後の課題点

今後検討すべき点としては，誤差を十分補いうる簡 単で効率的な較正法，コンタクトレンズ状磁石の眼球 等に対する安全性の評価等がある。また，この磁石は， 磁性粉体を相当量混合しているため, 脆く, 加工が難 しい.このため，他の製作法を検討している.

\section{1. 深部体温計による脳死の診断}

東京医歯大 医用器材研

过隆之尼川達男

藤元登四郎

東京女子医大 第 2 病院

須磨幸蔵 竹内靖夫 城 間 賢二 大江 容子

1. はじめに

術後や麻酔後に意識が回復しない患者はまれではな いそそのような患者の予後を知ることは医師にとって は重要である。

2. 方法ならびに対象

演者らは深部体温計を用いそのような患者の前額， 腹部や足底深部温を直腸温とともに連続計測し，頭部 表面冷却を行って，それらの体温の変動を観察した. さらに脳神経外科で植物人間と診断された患者につい ても同様に行った。

3 . 結果

植物人間と診断された症例では前額深部温が表面冷 却によっても足底深部温より低下しないが，腷血管造 影で no-filling が観察され脳死と診断された症例の場 合にはそれが低下して $2^{\circ} \mathrm{C}$ 以上両深部温が逆転した.

4. 考案ならびに結論

本法による脳死診断は脳血流の途絶を温熱負荷によ って間接的に知るものである.すなわち，脳血流が正 常であれば，頭部を表面冷却すれば各深部温は低下し て前額深部温のみが低下することはない。

現在の脳死の診断法では脳幹死を脳死とする可能性 もあり，前頭葉に血流が維持されている場合も含まれ る可能性がある。それに対して，本方法による診断で は前頭葉の血流停止または全脳死のみを脳死と㟝断で
きると考えられる.

本装置は X-CT, SPECT や MRI に比べて安価で 軽量であり, 脳死症例が発生しやすい第一線病院でも 使用でき，脳死診断に有用である.

\section{2.コンピュータ制御による疼痛点探索・刺激 鎮痛機器の開発 : (1)プロトタイプの試作}

\author{
東京医大霞ヶ浦病院 麻酔科 \\ 伊藤樹史 川端正博 \\ 須田高之舆水健治 \\ アイカ
}

山口宣明

[はじめに】

近年, 疼痛の治療部門であるペインクリニックにお いて, 年々増加する高歯者の痛みに対応するため種々 の鎮痛法が研究されている. 高龄者患者は痛みの外に 幾つかの病気を有するため幾種類もの薬物の服用に迫 られている. かかる患者に十分な鎮痛薬を使用するこ とは副作用の問題から困難なことも多く, 長期にわ たる疼痛のコントロールは不満足である. 高齢者はこ れ以上の濃厚な治療は好まず，古来から行われている マッサージや針治療等の東洋医学的治療や漢方薬に大 きな期待を寄せている. そこで従来から行われてきた 針治療をより科学的にとらえ, マイクロコンピュータ 制御下で人体に無数に点在する “ツボ”ゃ“経絡” を容易に探索かつ刺激が可能な疼痛点探索刺激装置 (PPSS) を開発した.これによって高齢者の痛みを除 去もしくは緩和させ, 社会復帰あるいは安秦生活を維 持できるならば幸いである，ハードウエアーは表示 部, 探索部, 刺激部が基本となる.これ注疼痛点 (ツ ボ）探索／刺激の両機能を有する電極（以下SS 電極） と 1 極の不感電極から構成されている. SS 電極は所 定面積の先端内に16個の点状電極を有し，これを用い て不感電極に戻る電流を検出し, 電圧に変換し, 疼痛 点の位置および大きさを表示し，これをメモリーする。 探索から得たデータはマイクロコンピュータによりリ アルタイムで疼痛点 (ツボ) の識別を行い刺激鎮痛を 行う. 刺激部は同一 SS 電極の探索部内にある制御部 で制御された刺激パルス電流を漸増させながら所定の 值までもって行く. 刺激頻度は $1,3,10,45,125$ [Hz]が選択でき, 刺激時間は $0-99$ 秒, あるいは 0-99分まで電子タイマーによって設定することがで きる. 今回は開発機器の紹介と臨床成績の一部につい て報告する。 